\title{
Influence of Pollination Technique on Greenhouse Tomato Production
}

\author{
Y.Z. Al-Attal' ${ }^{1}$, M.A. Kasrawi ${ }^{2}$ and I.K. Nazer ${ }^{2 \star}$ \\ ${ }^{1}$ Integrated Pest Management Project, GTZ, Amman, Jordan. \\ ${ }^{2}$ Department of Horticulture and Plant Protection, Faculty of Agriculture, \\ University of Jordan, Amman 11942, Jordan.
}

\author{
تأثير وسائل التلقيح على إنتاج الطماطم داخل الدفيئات \\ يحيى العتال و محمود قصراوي وإبراهيم الناظر
}

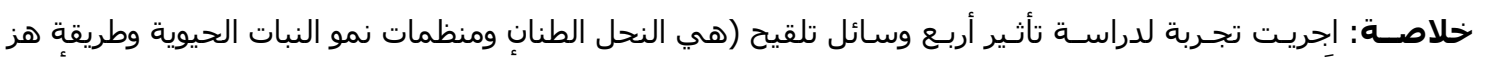

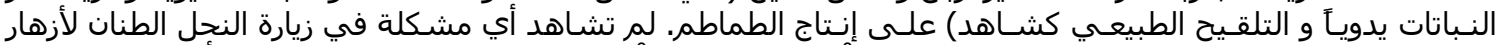

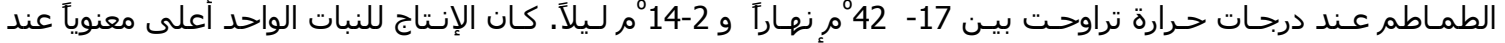

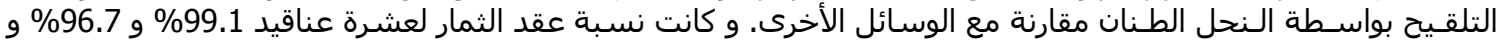

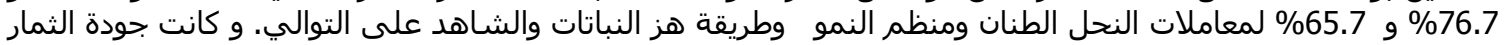

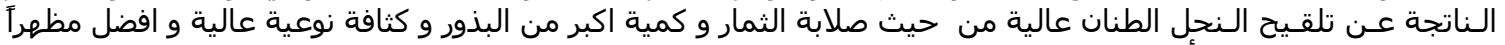

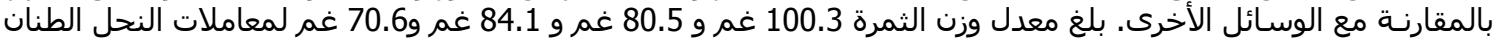

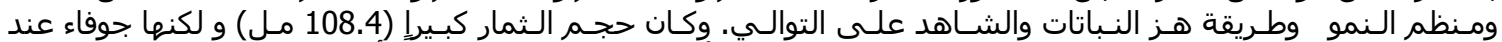

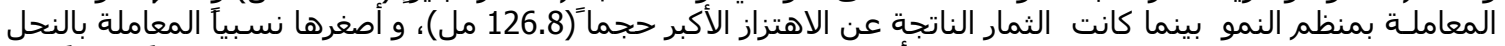

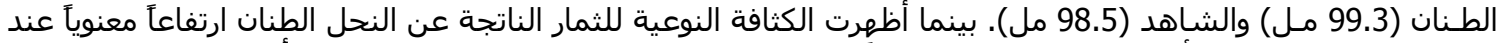

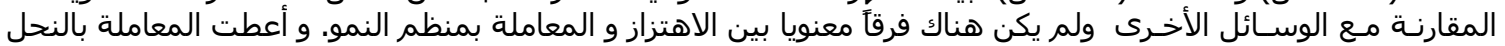

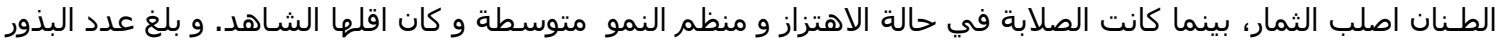

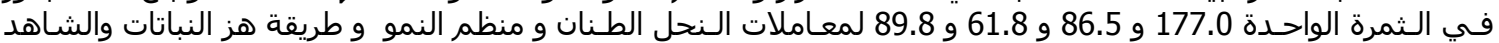
على التوالي.
\end{abstract}

\begin{abstract}
An experiment was carried out to study the effects of four pollination techniques; Bumblebees (Bombus terrerstris L.), plant growth bioregulator (PGB) (Parachlorophenoxy acetic acid), hand vibration, and control (natural pollination) on tomato (Lycopersicon esculentum Mill) production in greenhouses. Bumblebees showed no problem in visiting flowers at a temperature range of $17-42^{\circ} \mathrm{C}$ during the day and $2-14^{\circ} \mathrm{C}$ at night. Bumblebee pollinated plants produced a yield per plant which was significantly higher than plants treated with PGB, vibration and the control, respectively. Fruit set of tomato flowers over 10 clusters was 99.1, 96.7, 76.7, and $65.7 \%$ for bumblebee treatment, PGB application, vibration and the control, respectively. In the bumblebee pollinated flowers, the quality of fruits was superior. The fruits were hard, with more seeds, and had a high specific gravity and better appearance. The average fruit weight was $100.3,80.5,84.1$, and $70.6 \mathrm{~g}$ for the bumblebee, PGB, vibration and the control, respectively. The PGB treatment produced bigger sized but puffy fruits $(108.4 \mathrm{ml})$. While fruit size in the vibration treatment was the highest $(126.8 \mathrm{ml})$, followed by the bumblebee and the control which were 99.3 and $98.5 \mathrm{ml}$, respectively. Fruit specific gravity in the bumblebee treatment was significantly higher than other treatments, with no significant differences between the PGB and the vibration treatments. The least dense fruits were in the control treatment. Regarding the firmness of fruits, the bumblebee treatment gave the hardest fruits, while the PGB and the vibration treatments were intermediate and the control was the least. Average seed number per fruit was 177.0, 86.5, 61.8, and 89.8 for bumblebee, vibration, PGB and the control, respectively.
\end{abstract}

Keywords: Bumblebees, tomato, pollination, Jordan, plastichouse, greenhouse.

$\mathbf{T}$ o maximize fruit set in tomatoes and other crops, plant growth bioregulator (PGB) (Pak and Kim,1999), plant or truss vibration, honeybees (Kremen, 2001) and bumblebees (Paydas et al., 2000) are frequently used. Nelson and Richard (1989) found that electrical vibration is not practical and also tedious. Recently, a worldwide trend is to use the bumblebee as a pollinator on many crops including tomatoes due to yield increase and enhancement of fruit quality
(Delaplane, 1995). Proporato et al. (1993) used bumblebees for the pollination of tomatoes under polyethylene tunnels and found that plants gave better yield and quality fruits. In France, bumblebees colonies were used in tomato pollination and gave more effective pollination than mechanical vibration (Caudal and Trapateau, 1992). Ikeda and Tadauchi (1995) found that tomato fruits obtained by bumblebee pollination were more uniform and contained more seeds, flesh, 
acids and vitamin $\mathrm{C}$ contents than that obtained by plant growth bioregulator application.

Tomato (Lycopersicon esculentum Mill) is planted in the Jordan valley under plastichouses (i.e. greenhouses) during the months of October, November and December (Anonymous, 1998). Therefore, fruit set, fruit development and even maturity of several clusters occur during the cool climate in winter. Efficient pollination and successful fertilization of greenhouse tomato is needed to ensure maximum fruit set and the proper development of high quality fruits, specially during cool conditions (Dogterom et al., 1998; Ravestijin and Sande, 1991).

Although tomato flower is self fertile, the structure of the anther core, it's mode of dehiscence and the position of the style make some form of disturbance necessary to ensure adequate pollination in cool winter or in high summer temperatures (Raymond, 1985; Rylski et al., 1994). Banda and Paxton (1991) found that fruit setting of tomatoes grown in greenhouses is frequently poor and fruit set is very dependent on the use of mechanical aids.

The objective of this research was to compare three pollinating techniques, bumblebee, PGB and vibration, with respect to fruit set, yield, and fruit quality in greenhouse tomatoes.

\section{Materials and Methods}

All treatments were performed in two neighboring greenhouses in the Abu-Ubiedah area in the Jordan valley. No control on light, temperature or relative humidity inside the greenhouses was performed. "Argenta", a common long shelf life cultivar of greenhouse tomatoes used for exporting purposes was transplanted on the $10^{\text {th }}$ of November 1996.

Both greenhouses were identical and were $60 \mathrm{~m}$ long, $8 \mathrm{~m}$ wide, grown with 5 raised beds of tomatoes. The width of each bed was $0.5 \mathrm{~m}$. Two rows were planted in each bed and the distance between the beds was $1 \mathrm{~m}$. The space within rows in beds was $30 \mathrm{~cm}$ and between rows was $20 \mathrm{~cm}$. Beds were covered with black polyethylene plastic mulch and plants were irrigated by drip irrigation system.

The first $20 \mathrm{~m}$, the last $20 \mathrm{~m}$ of raised beds, and beds on both sides of the greenhouse were excluded from the experimental area to decrease variation among plots. A randomized complete block design with three replicates was used.

Each bed (which includes two rows) was divided into three plots and each plot was randomly assigned to each treatment. In greenhouse B, the PGB, the vibration and control treatments were conducted, while in greenhouse $\mathrm{A}$, the treatment was only bumblebee. In both greenhouses, the number of plants in each plot was 10. At random, from the 10 plants in each plot, 4 plants were labeled for yield measurement (productivity plants), three plants were used for quality parameter evaluation (quality plants) and three for substitution. Temperature and relative humidity were recorded each day by a thermo-hygrograph and minimax thermometer.

A bumblebee hive, with an estimated 80 workers, was placed inside the greenhouse (A) on 10 December and removed on 1 April with the termination of flowering clusters. The hive was placed for $24 \mathrm{hrs}$ in the experimental greenhouse, then removed and returned after $48 \mathrm{hrs}$.

The PGB (para-chlorophenoxyacetic acid $7 \mathrm{gm} / 1$. 4-CPA) was used in the PGB application treatment. The PGB was diluted by taking the proper amount from the stock solution in one liter of tap water according to the label instructions. Three $\mathrm{ml}$ from the stock were applied when the temperature was lower than $20^{\circ} \mathrm{C}$ and $2 \mathrm{ml}$ when the temperature was more than $20^{\circ} \mathrm{C}$. The application was done by using a hand sprayer of $1 \mathrm{~L}$ volume. One spray was applied on each flower cluster. Spraying was carried out in synchronization with flower anthesis. Twenty-one sprays were applied between 10 December 1996 and 1 April 1997.

In the vibration treatment, plants were hand vibrated each day in the morning between 10-11 a.m. for 3-5 seconds. The control plants were not treated. Vibration was performed between the $10^{\text {th }}$ of December and the $1^{\text {st }}$ of April.

Fruit set percentage was calculated in each flower cluster in the productivity labeled plants in each plot until the end of fruit set on the $11^{\text {th }}$ cluster. At maturity, fruits of the first nine flower clusters were harvested and average fruit weight and total yield for each cluster were recorded.

At harvesting, size, weight, specific gravity, firmness of fruit, and number of seeds per fruit were measured. For fruit quality, fruit numbers 1, 3, and 5 from cluster number 1,3 , and 5 on each of the three quality labeled plants were assigned. Fruit size was determined by the water replacement method, then the specific gravity of the fruit was computed, the total of 81 fruits was measured.

Seed extract was made from fruit number 3 of cluster numbers 1,3 , and 5 for each quality labeled plants. The number of seeds inside each fruit was counted. A total of 27 fruits was used to measure this parameter in each treatment.

A fruit pressure tester was used to measure flesh firmness in fruit number 1 of clusters 1,3 , and 5 of quality plants. Testing began by removing the epidermal layer of tomato fruit with a sharp knife on the two opposite sides, then flesh firmness was measured and the average of two readings was calculated. A total of 27 fruits was tested in each treatment.

\section{Results and Discussion}

YIELD: Bumblebee pollinated tomato flowers produced significantly the highest average fruit weight and yield per 
TABLE 1

Yield per plant, fruit weight, fruit size, seed number, firmness, and specific gravity in the bumblebee, plant growth bioregulator (PGB), vibration and control treatments of greenhouse tomatoes.

\begin{tabular}{|c|c|c|c|c|}
\hline \multirow{2}{*}{ Parameter } & \multicolumn{4}{|c|}{ Treatment } \\
\hline & Bumblebees & PGB & Vibration & Control \\
\hline Average yield per plant (g) & $5132.20 \mathrm{a} *$ & $4116.80 \mathrm{~b}$ & $3591.00 \mathrm{c}$ & $2818.50 \mathrm{~d}$ \\
\hline Average fruit weight (g) & $100.30 \mathrm{a}$ & $80.50 \mathrm{~b}$ & $84.10 b$ & $70.60 \mathrm{c}$ \\
\hline Average fruit size $\left(\mathrm{cm}^{3}\right)$ & $99.30 b$ & $108.40 \mathrm{ab}$ & $126.80 \mathrm{a}$ & $98.50 \mathrm{~b}$ \\
\hline Average seed number per fruit & $177.00 \mathrm{a}$ & $61.80 \mathrm{c}$ & $86.10 \mathrm{~b}$ & $89.80 \mathrm{~b}$ \\
\hline Firmness $\left(\mathrm{Kg} / \mathrm{cm}^{2}\right)$ & $3015.80 \mathrm{a}$ & $2690.00 \mathrm{ab}$ & $2846.10 \mathrm{ab}$ & $2464.40 \mathrm{~b}$ \\
\hline Average fruit specific gravity $(\mathrm{g} / \mathrm{ml})$ & $1.03 \mathrm{a}$ & $0.96 \mathrm{~b}$ & $0.983 b$ & $0.95 \mathrm{c}$ \\
\hline
\end{tabular}

* Numbers having same letters in the same row are not significantly different at $\mathrm{p}=0.05$ according to Duncan Multiple Range Test.

plant than the other treatments. The lowest average fruit weight and the lowest yield per plant were produced from the control tomato plants (Table 1) (Figure 1). Paxton and Banda (1991) found that the bumblebee pollination is the best means of pollination regarding the tomato yield per plant. Ikeda and Tadauchi (1995) reported that the use of bumblebees gave a higher yield than the application of PGB. However, Fiume and Parisi (1994) found that PGB application is slightly better than bumblebee pollination in tomato. This yield increase is due to higher number of pollen grains that fertilize the ovules and consequently the higher number of seeds per fruit that contributed to a higher fruit weight.

The temperature throughout the flowering, growth and fruit development stages ranged from $2-14^{\circ} \mathrm{C}$ at night to $17-42^{\circ} \mathrm{C}$ during the day. This high fluctuation in temperature, the low night temperature at the stage of flower formation, in addition to stigmatic elongation on hot days will lead to poor fruit set in both vibration and control treatments. This could be related to poor pollination or poor fertilization. In the bumblebee treatment, buzz-pollination will overcome stigmatic elongation. Bumblebees visit a high number of flowers each day. This increases the possibility of transferring viable pollen. Also, a high relative humidity in winter days makes pollen clump. As a result no transfer of pollen grain to the stigma occurs in both the control and vibration treatments. In several clusters in the PGB treatment many fruits were seedless indicating that PGB application induces fruit set. This takes place regardless of the climatic conditions. Consequently these fruits will have a lower density. One or more of these factors may play a role in the difference between the effect of the treatments over each cluster.

AVERAGE Yield AND Fruit SET (Cluster Wise ANALYSIS): In general, the average cluster yield and fruit weight were significantly higher in the bumblebee treatment than the other treatments. However, in some clusters there were no significant differences via the treatments or the significance was between the treatments and the control only.

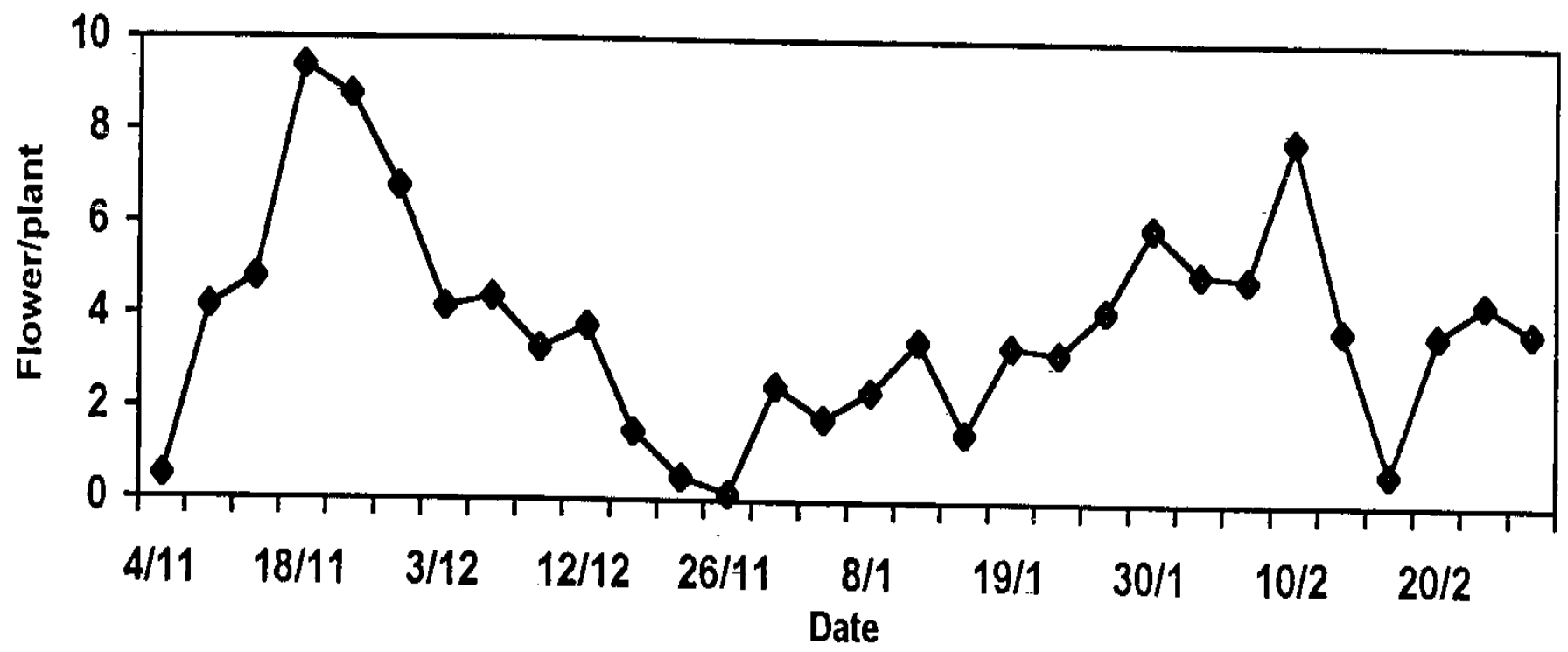

Figure 1. Average number of greenhouse tomato flowers per plant during the flowering period. 
TABLE 2

Average fruit weight and yield per tomato plant in the bumblebee, plant growth bioregulator (PGB), vibration and control treatments cluster wise analysis.

\begin{tabular}{|c|c|c|c|c|c|c|c|c|}
\hline \multirow[b]{2}{*}{ Cluster } & \multicolumn{2}{|c|}{ Bumblebee } & \multicolumn{2}{|c|}{ PGB } & \multicolumn{2}{|c|}{ Vibration } & \multicolumn{2}{|c|}{ Control } \\
\hline & $\begin{array}{c}\text { Average } \\
\text { fruit }\end{array}$ & $\begin{array}{c}\text { Average } \\
\text { yield }\end{array}$ & $\begin{array}{c}\text { Average } \\
\text { fruit }\end{array}$ & $\begin{array}{c}\text { Average } \\
\text { yield }\end{array}$ & $\begin{array}{c}\text { Average } \\
\text { fruit }\end{array}$ & $\begin{array}{c}\text { Average } \\
\text { yield }\end{array}$ & $\begin{array}{c}\text { Average } \\
\text { fruit }\end{array}$ & $\begin{array}{c}\text { Average } \\
\text { yield }\end{array}$ \\
\hline 1 & $93.0 \mathrm{a}^{*}$ & $619.6 \mathrm{a}$ & $88.2 \mathrm{a}$ & $428.7 b$ & $91.4 \mathrm{a}$ & $278.7 \mathrm{bc}$ & $70.8 \mathrm{a}$ & $192.0 \mathrm{c}$ \\
\hline 2 & $111.1 \mathrm{a}$ & $630.3 \mathrm{a}$ & 78.9ab & 495.0ab & $89.8 \mathrm{ab}$ & $351.2 \mathrm{bc}$ & $75.6 c$ & $244.1 \mathrm{c}$ \\
\hline 3 & $97.1 \mathrm{a}$ & $652.3 \mathrm{a}$ & $84.7 \mathrm{a}$ & $463.7 b$ & $88.2 \mathrm{a}$ & $374.2 \mathrm{bc}$ & $71.1 \mathrm{a}$ & $312.3 \mathrm{c}$ \\
\hline 4 & $93.3 \mathrm{a}$ & $578.8 \mathrm{a}$ & $80.0 \mathrm{ab}$ & 483.3ab & $79.8 \mathrm{ab}$ & $516.0 \mathrm{ab}$ & $70.3 \mathrm{c}$ & $399.0 \mathrm{c}$ \\
\hline 5 & $110.0 \mathrm{a}$ & $607.8 \mathrm{a}$ & $82.5 b$ & $534.5 \mathrm{ab}$ & $85.6 \mathrm{~b}$ & $590.8 \mathrm{ab}$ & $78.3 b$ & $445.0 \mathrm{c}$ \\
\hline 6 & $108.2 \mathrm{a}$ & $689.3 \mathrm{a}$ & $76.3 b$ & $489.5 \mathrm{ab}$ & $90.8 b c$ & $495.0 \mathrm{~b}$ & $66.2 \mathrm{c}$ & $374.3 b$ \\
\hline 7 & $100.6 \mathrm{a}$ & $633.0 \mathrm{a}$ & $73.3 b$ & $434.3 b$ & $85.6 \mathrm{c}$ & $345.0 \mathrm{~b}$ & $64.4 \mathrm{~d}$ & $271.5 b$ \\
\hline 8 & $94.5 \mathrm{a}$ & $650.0 \mathrm{a}$ & $73.6 \mathrm{~b}$ & $418.0 \mathrm{~b}$ & $70.5 b$ & $316.9 b$ & $66.8 b$ & $287.0 \mathrm{~b}$ \\
\hline 9 & $95.1 \mathrm{a}$ & $650.0 \mathrm{a}$ & $86.6 \mathrm{a}$ & $369.8 b$ & $75.6 b$ & $323.0 \mathrm{~b}$ & $71.5 b$ & $283.3 b$ \\
\hline Average fruit $(\mathrm{g})$ & $100.3 \mathrm{a}$ & - & $80.5 b$ & - & $84.1 \mathrm{~b}$ & - & $70.6 \mathrm{c}$ & - \\
\hline Average plant yield (g) & - & $5132.2 \mathrm{a}$ & - & $4116.8 b$ & - & $3591.0 \mathrm{c}$ & - & $2818.5 d$ \\
\hline
\end{tabular}

* Numbers having same letters in rows for the same parameter are not significantly different at $\mathrm{P}=0.05$ according to Duncan Multiple Range Test.

According to the climatic conditions throughout the flowering period, as in cluster four, the vibration treatment was significantly higher than the PGB (Table 2) (Figure 2).

The overall average fruit set by the bumblebee treatment was $(99.1 \%)$ with no significant difference with that of PGB treatment (96.7 \%). Both bumblebee and PGB treatments gave significantly higher fruit set percentage than the vibration $(76.5 \%)$ and the control $(65.3 \%)$ (Table 3$)$.

In the first, second, seventh, and eighth clusters, the average fruit set in all clusters was similar in the bumblebee and PGB treatments. Both were significantly higher than vibration and control treatment. In the third cluster, there was no significant difference in fruit set among treatments, but all were higher than the control. In the fourth and ninth clusters, fruit set in all treatments was not significantly different, but the bumblebee and the PGB application gave significantly higher fruit set than the control. In the fifth and sixth clusters, there were no differences in fruit set percentage between the treatments and the control. In the tenth cluster, the bumblebee treatment and the bioregulator application were not significantly different but they gave higher fruit set than the vibration. Also, the vibration was higher than the control. In the eleventh cluster, bumblebee treatment ranked first in fruit set percentage, than the PGB application and vibration while the control was the least with no significant difference between all treatments. The low fruit set in the vibration and the control treatments in the first and the second cluster may be due to poor pollination and to poor fertilization in cool nights $\left(2-14^{\circ} \mathrm{C}\right)$ and to high day temperature $\left(31-42^{\circ} \mathrm{C}\right)$. During the fruit set period of cluster three, the average night temperature was $12^{\circ} \mathrm{C}$ and day temperatures was $31^{\circ} \mathrm{C}$. This gave good pollination in all treatments and the control resulting in good fruit set. In the seventh and eighth clusters the day temperature had risen to $38^{\circ} \mathrm{C}$ and induced stigmatic elongation. In the ninth, tenth and eleventh clusters fruit set in the vibration treatment, decreased significantly due to a high day temperature $\left(38^{\circ} \mathrm{C}\right)$, and to the fact that in this period of growth, the plants were near the plastic sheets which cause stigmatic elongation.

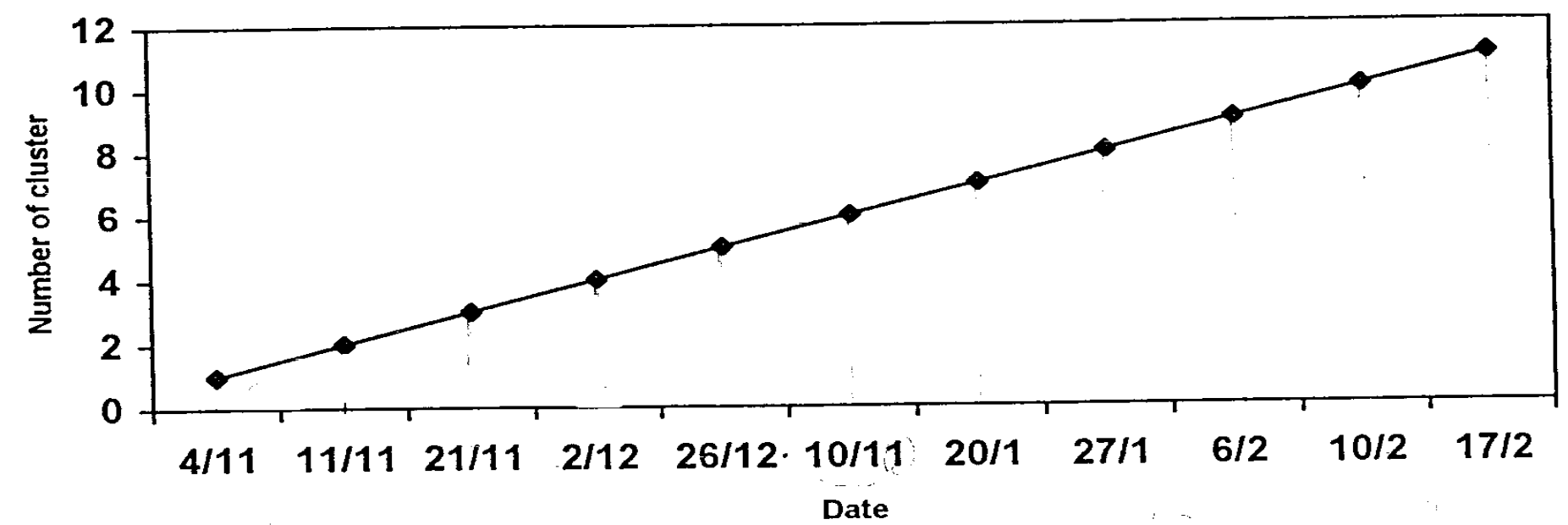

Figure 2. The date of anthesis of tomato clusters 1-11 in 0.5 dunum greenhouse in 1996. 
INFLUENCE OF POLLINATION TECHNIQUE ON GREENHOUSE TOMATO PRODUCTION

TABLE 3

Average fruit set percentage in greenhouses tomato pollinated bumblebees, plant growth bioregulator (PGB), vibration and control treatment.

\begin{tabular}{ccccc}
\hline & \multicolumn{3}{c}{ Treatment } \\
\cline { 2 - 5 } Cluster & $\begin{array}{c}\text { Bumblebee } \\
(\%)\end{array}$ & $\begin{array}{c}\text { Plant Growth Bio } \\
\text { Regulator }(\%)\end{array}$ & $\begin{array}{c}\text { Vibration } \\
(\%)\end{array}$ & $\begin{array}{c}\text { Control } \\
(\%)\end{array}$ \\
\hline 1 & $100.0 \mathrm{a} *$ & $97.8 \mathrm{a}$ & $73.9 \mathrm{~b}$ & $63.1 \mathrm{~b}$ \\
2 & $100.0 \mathrm{a}$ & $98.1 \mathrm{a}$ & $73.3 \mathrm{~b}$ & $74.6 \mathrm{~b}$ \\
3 & $98.7 \mathrm{a}$ & $94.0 \mathrm{a}$ & $89.6 \mathrm{a}$ & $75.3 \mathrm{~b}$ \\
4 & $100.0 \mathrm{a}$ & $98.0 \mathrm{a}$ & $91.2 \mathrm{ab}$ & $82.6 \mathrm{a}$ \\
5 & $100.0 \mathrm{a}$ & $99.3 \mathrm{a}$ & $89.8 \mathrm{a}$ & $78.0 \mathrm{a}$ \\
6 & $100.0 \mathrm{a}$ & $93.0 \mathrm{a}$ & $74.1 \mathrm{a}$ & $51.0 \mathrm{~b}$ \\
7 & $99.5 \mathrm{a}$ & $94.3 \mathrm{a}$ & $54.8 \mathrm{~b}$ & $52.0 \mathrm{~b}$ \\
9 & $94.4 \mathrm{a}$ & $94.9 \mathrm{a}$ & $63.9 \mathrm{~b}$ & $54.1 \mathrm{~b}$ \\
11 & $98.5 \mathrm{a}$ & $99.3 \mathrm{a}$ & $75.6 \mathrm{ab}$ & $61.5 \mathrm{c}$ \\
Average & $99.7 \mathrm{a}$ & $97.8 \mathrm{a}$ & $75.6 \mathrm{bc}$ & $71.5 \mathrm{c}$ \\
\hline
\end{tabular}

* Numbers having same letters are not significantly different at $\mathrm{P}=0.05$ according to Duncan Multiple Range Test.

In the bumblebee treatment, it seems that the bumblebee individual usually carries viable pollen grains which gives better yields than the PGB under temperature between $\left(2-14^{\circ} \mathrm{C}\right)$ at night and $\left(17-42^{\circ} \mathrm{C}\right)$ during the day.

QUALITY PARAMETERS: There was a significant difference in the average fruit weight between the different treatments (Table 1). Regarding fruit size, there was no significant difference between the fruit size in the bumblebee, PGB and the control treatment. The largest fruit size was in the vibration treatment, $126.8 \mathrm{ml}$, followed by PGB, $108.4 \mathrm{ml}$. The bumblebee and control treatment gave the least fruit size, $99.3 \mathrm{ml}$, and $98.5 \mathrm{ml}$, respectively (Table 1).

Fruit density in the bumblebee treatment was significantly higher than other treatments. There was no significant difference between the PGB and vibration treatments. The least dense fruits were in the control. PGB does not increase cell division in tomato, but the increase in size is related to cell elongation, that resulted in many cavities and lighter fruits. In the vibration and control treatments density was correlated with the number of seeds (Table 1).

Regarding the firmness of the fruits, the bumblebee treatment gave the hardest fruits, while the PGB treatment and vibration gave intermediate results. The control fruits were the least firm (Table 1).

Seed number per fruit was significantly higher in the bumblebee treatment (177.0). The lowest seed number was in the PGB treatment (61.8). There was no significant difference in the number of seeds between the control and the vibration treatments 89.8 and 86.1, respectively (Table 1 ).

The large tomato fruit size from PGB treatment was related to the effect of the bioregulator on cell elongation but with very low seed number inside the fruit. The vibration treatment produced low fruit set and lower number of fruits per cluster and plant, which may be compensated for by the larger size.

The lower number of seeds per fruit was for the vibration and control treatments. The bumblebee individual has a special buzzing pollination tactic. This ensures more contact between the pollen grains on the stigma. In the control, apparently the same number of pollen grains will fertilize the ovule due to deliberate vibration to increase fruit set and to workers movement and wind circulation. This of course was not as efficient as the buzzing effect of bumblebees. Paxton and Banda (1991) have similar results, i.e, that bumblebees resulted in fruits with higher number of seeds, and higher weight than the vibration or the control. Vecchio et al. (1996) found that the application of PGB will speed up the ripening of fruits by about one week.

SHAPE OF THE FRUITS: Flowers pollinated by bumblebees gave fruits that looked better in shape and were plump without puffiness, had more seeds, and a higher specific gravity, were harder, and were uniform color. These characteristics make fruits more preferable for local and export markets. Plants that were treated with PGB produced puffy, soft fruits, with relatively lower specific gravity than other treatments, and the color some times is not uniform. In the vibration treatment, the fruits are plump but usually the size was larger than the others with a lower number of seeds as compared to the fruits from the bumblebee treatment. Fruits of the control were smaller than those in the other treatments.

\section{Conclusions}

The results indicated that bumblebees could be used successfully in greenhouses for tomato plant 


\section{AL-ATTAL, KASRAWI, AND NAZER}

pollination. Bumblebee-pollinated tomatoes gave higher yield, higher number of seeds, better weight-size correlation, higher specific gravity and higher fruit firmness than other pollinating agents; plant growth bioregulator and plant vibration.

\section{Acknowledgement}

The authors express their gratitude to the Deanship of Scientific Research at Jordan University for the partial financial support of this research. Sincere thanks are extended to Mr. Khalil Abu-Ghannam for his offer to conduct this research at his farm and for his valuable suggestions and help through out the study. The comments and the revision of the article by Dr. Valkmar Hasse is greatly acknowledged.

\section{References}

Anonymous. 1998. Department of Statistics. Statistical Year Book, (1990-1997), The Hashemite Kingdom of Jordan.

Caudal, T.Y. and Trapateau. 1992. Pollination of tomatoes, the use of bumblebee under glass. Info-Paris 80:43-46.

Delaplane, K.S. 1995. Why bumblebees. American Bee Journal 135:459-460.

Dogterom, M.H. J.R., Matteoni, and R.C. Plowright. 1998. Pollination of plastichouse tomatoes by the North American Bombus vosnesenskii (Hymenoptera: Apidae). Journal of Economic Entomology 91:71-75.

Fiume, F. and B. Parisi. 1994. PGB and pollinating Bombidae insects on tomato fructification (protected cultivations Italy). Colture Protette 23:87-93.

Ikeda, F. and Y. Tadauchi. 1995. Use of bumblebees as pollinators on fruits and vegetables. Honeybee Science 16:49-56.

Kremen, C. 2001. Organic Farming Research Foundation Project Report \# 99-07 [On line]. http://www.ofrf.org/research/researchreports.html.

Nelson, P. and M. Richard. 1989. Pollination of plastichouse muskmelon by bumblebees (Hymenoptera: Apidae). Journal of Economic Entomology 82:1061-1066.

Pak, H. and D. Kim. 1999. ISHS Acta Horticulturae [On line]. (http://www.ishs.org/pub/483.html).

Paydas, S., S. Eti, O. Kaftanglu, E. Yasa, and K. Derin. 2000. ISHS Acta Horticulturae [On line]. (http://www.ishs.org/pub/513.html).

Paxton, R.J. and H.J. Banda. 1991. Pollination of plastichouse tomatoes by bees. Acta Horticulturae 288:194-198.

Porporato, M., M. Pinna, A. Manino, and F. Marletto. 1995. Pollination of sweetpepper under protected cultivation by Bombus terrestris L. and Apis mellifera L. Apicoltore Moderno 86:99112.

Ravestijin, W. and J. Sande. 1991. Use of bumblebees for the pollination of glasshouse tomatoes. Acta Horticulturae 288:342-345.

Raymond, G. 1985. Solanaceae. In: Vegtable Seed Production. 1st edition, Longham House, Burnt Mill. Harlow.

Rylski, L. B. Aloni, L. Karni, Z. Zaidman, K. Cockshull, Y. Tuzel, and A. Gul. 1994. Flowering, fruit set, fruit development and fruit quality under different environmental conditions in tomato and pepper crops. Acta Horticulture. 366:45-55.

Received July 2002.

Accepted Jan 2003. 